
and adolescents. Journal of Education, Health and Sport. 2020;10(5):11-18. eISSN 2391-8306. DOI http://dx.doi.org/10.12775/JEHS.2020.10.05.001

https://apcz.umk.pl/czasopisma/index.php/JEHS/article/view/JEHS.2020.10.05.001

https://zenodo.org/record/3784508

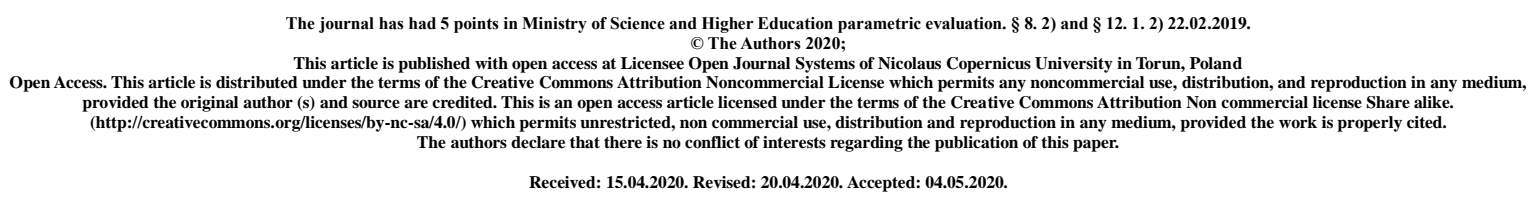

\title{
Causes of overweight and obesity in children and adolescents
}

\author{
Agnieszka Maślak ${ }^{1}$, Monika Kusz ${ }^{1}$, Paulina Pawluczuk ${ }^{1}$, Adam Alzubedi ${ }^{2}$, \\ Pawel Polski ${ }^{2}$
}

1. Department of Paediatric Nephrology, Medical University of Lublin

2. Department of General and Transplant Surgery and Nutritional Treatment, Medical

University of Lublin

\begin{abstract}
Obesity is caused by positive energy balance. Excessive body weight in children is classified by using charts for body mass index (BMI). The prevalence of overweight and obesity is a growing public health problem worldwide. Excess body fat may lead to serious health problems in later life, so it is important to know the main reasons causing weight gain. Those could be classified as genetic and non-genetic factors. The second ones include medical problems (e.g. endocrine and neurological diseases), family and social impact, environmental influence, bad eating habits, sedentary lifestyle, cultural factors. There are two most important phases in life such as infancy and puberty, which may determine development of overweight or obesity. It is crucial to pay special attention on those periods to prevent weight gain development.
\end{abstract}

Key words: overweight, obesity, diet 


\section{Introduction}

Obesity is defined as an excess of body fat caused by the positive energy balance, which means that more energy is taken than expended [1]. For children and adolescents, overweight and obesity are classified by using age and sex specific charts for body mass index (BMI). BMI is a person's weight in kilograms divided by the square of his height in meters $(\mathrm{kg} / \mathrm{m} 2)$. Children with BMI equal to or over the 95th percentile are considered to be obese and those with BMI between the 85 th to 95 th percentiles are considered to be overweight $[2,3]$.

Overweight and obesity in the child and adolescent population is a growing problem worldwide. The prevalence of overweight and obesity in youths has risen from $4 \%$ in 1975 to over $18 \%$ in 2016. In 2018, about 40 million children under 5 years old were overweight or obese. In 2016, this problem affect over 340 million children and adolescents from 5 to 19 years old [2].

Excessive weight in young people contributes to the emergence of co-morbidities such as type 2 diabetes mellitus, dyslipidemia, hypertension, non-alcoholic fatty liver disease, obstructive sleep apnoea, coronary heart disease, cholelithiasis, orthopaedic complications, precocious puberty, postural defects e.g. scoliosis and psychological problems like lowered self-esteem, depression, peer discrimination $[1,4,5,6]$. Those factors can reduced the quality and length of life [4].

Obesity has various causes and it is a multi-factorial condition determined by genetic, behavioural, environmental and cultural factors [7,8]. Genetic variations play an important role in individual predisposition, but other determinants like behaviour and environment may also have crucial impact on childhood obesity [9].

\section{Genetic factors}

Genetic factors play the role in pathogenesis of obesity in about 40-70\%. In some cases genetic variations completely determine obesity development, in other it is a close interaction between genes and the environment [10]. It was found that the risk of developing overweight or obesity is 4-5 times higher when one parent is obese. However this probability increases 13 times when both parents are obese [11]. For 3 years old child parental obesity is a stronger predictor of obesity in adulthood than the weight status of this infant [3].

There are lots of genes responsible for insulin sensitivity, activity of enzymes regulating lipids metabolism and it's oxidation. Genes have also an impact on taste preferences and body weight stability [10]. It could be single gen defect e.g. abnormalities in leptin signalling pathway or melanocortin-4 receptor defect [12]. Obesity can also be a manifestation of some genetic syndromes including Prader-Willi syndrome, Bardet-Biedl syndrome, Alstrom syndrome, WAGR syndrome and Cohen syndrome [3,12].

Knowledge of genetic aspects of obesity is important to understand some difficulties in losing weight among children from families prone to accumulate fat in response to the positive energy balance [10]. 


\section{Appetite regulating factors}

Energy metabolism and appetite regulation depend on complex neuroendocrine interactions, which control food intake and energy use. Interactions between orexigenic (appetitestimulating) and anorexigenic (reducing appetite and food intake) factors have an affect on energy balance, which result in body weight gain or loss $[3,12]$.

The most important hormones that affect appetite regulation are leptin, ghrelin and insulin. Leptin is a protein produced by matured adipocytes [13] and acts in the hypothalamus where inhibits neuropeptyde $\mathrm{Y}$ synthesis $[3,13]$. Leptin is a major anorexigenic hormone and it's concentration depends on adipose tissue amount [13].

Fasting and weight loss decrease plasma concentration of leptin and insulin, which increase food intake and lower energy expenditure by increasing neuropeptide $\mathrm{Y}$ synthesis, and probably by inhibiting catabolism. Conversely, high leptin and insulin concentration throughout eating and weight gain decrease food consumption and increase energy use by releasing melanocortin and corticotropin-releasing hormone [3].

Other anorexigenic hormones, which are secreted by the gastrointestinal tract, include: peptide tyrosine tyrosine (PYY), pancreatic polypeptide, oxyntomodulin, amylin, glucagon, glucagon-like peptide-1 (GLP-1) and GLP-2 [12]. The major orexigenic peptides are orexins A and B- secreted by the hypothalamus, and ghrelin- secreted by the stomach [3]. Ghrelin increase appetite through activation of the neuropeptyde Y receptors [13].

\section{Endocrine and neurological pathology}

There are some endocrine diseases associated with obesity, including hypothyroidism (primary or central), growth hormone deficit or resistance and cortisol excess. Polycystic ovarian syndrome (PCOS) could be both a reason and a consequence of obesity. Pseudohypoparathyroidism (caused by Gs $\alpha$ inactivating mutation) is also related to obesity. Albright hereditary osteodystrophy (AHO) is an example of such disorder, which is a result of germline mutations in GNAS1 what causes decreasion in expression or function of Gsalpha $(\mathrm{Gs} \alpha)$ protein.

Also pathology associated with central nervous system results in obesity. Congenital or acquired hypothalamic deficiencies cause severe form of obesity in youths. Acquired hypothalamic damage induced by infiltrative diseases, tumors or treatment of this conditions leads to obesity syndrome characterized by a rapid, uncontrolled weight gain that may include severe hyperphagia.

This abnormal weight gain is due to disruption in natural homeostasis between hunger's and satiety's controlling centres. When the specific regions in hypothalamus become damaged, it results in hyperphagia, imbalance in autonomic nervous system, hyperinsulinemia, and decrease in energy expenditure. All of this changes lead to unrelenting weight gain [12].

\section{Fundamental phases in evolution of obesity}

It is believed that the critical phases for development and maintenance of obesity are infancy and puberty [14]. There is close relationship between birth weight and BMI evaluatation later in life. Higher birth weight is associated with increasing prevalence of obesity. Babies small to gestational age show abdominal fat deposition and insulin resistance which also increase a risk of obesity in childhood $[3,12]$. 
Rolland-Cashera et al. show that major of infant usually lose an access of their adipose tissue about 2 years of old, when they physical activity increase. In the next years the amount of adipose tissue increase again, what is called adiposity rebound. The highest level of BMI is observed about 8 years of old, and later in life child's weight remain in the same percentile [15]. Several studies found that an early rebound is positively correlated with prevalence of overweight in adulthood [12].

The last period in childhood, which increase a risk of obesity development in later life is adolescence. Early menarche is closely related to the severity of obesity in adulthood [16].

It is suggested that up to $80 \%$ of overweight adolescents become obese adults [3]. Moreover, Kasley et al. proves that health consequences of obesity in childhood could be still present even if the body mass will back to normal. It is suggested that developmental period leaves a specific imprinting that increase mortality and morbidity rate regardless of mature person's BMI [15].

\section{Family and social aspects}

Parent's habits have a great impact in child's eating behaviours and physical activity, especially among those in age of 5 to 11 . After this period parental influence may be small because of the increasing impact of peers' preferences $[1,17,18]$. However, children's eating habits develop early in life so parental behaviours modify child's food choices $[1,3]$.

Parenting style, which provides family principles and routines may influence children's behaviour [19]. For instance family meals reduce time spending in front of TV screen and enhance quality of the diet, parents' support and partnership in physical activity causes greater physical activity in children, while settling limits of TV watching decrease the screen time $[9,18,19]$. They are also responsible for availability and variety of food. There is a positive connection between sufficient amount of fruits and vegetables at home and it's consumption by kids [6].

Parental factors, especially maternal ones, have an impact on child's overweight as soon as in prenatal stages. Prenatal factors which are positively linked to obesity in early childhood include maternal obesity before pregnancy, maternal nutrition, high weight gain (more than 20 $\mathrm{kg}$ ) and smoking during pregnancy, maternal depression in the prenatal stage and gestational diabetes mellitus. Mother's obesity early in the pregnancy almost twice increase prediction of development overweight or obesity in $4-5$ years old children [20,21,25]. On the other hand, malnutrition of pregnant woman, especially deficiency in protein, iron and zinc intake can lead to dysfunction of placenta which may cause overweight or obesity later in children's life [11]. Breastfeeding has protective effect on child's weight, especially when it lasts more than 16 months [8]. Breastfeeding is also correlated with healthier feeding practice in childhood e.g. lower consumption of ultra-processed food and sweetened beverages [22]. Instead, overfeeding even in the first day of life has positive impact on the development of overweight and obesity as well as introducing solid foods before 4 months after birth which may result in greater consumption of meals reach in fat and sugar [20,23]. In addition, Rocha et al. study shows that girls of mother who felt safe in a household presented less risk of development overweight in about $40 \%$ [8].

Socio-economic status has also an effect in the development of healthy feeding practices. Some studies show the negative correlation between socio-economic status of developed 
countries and prevalence of overweight and obesity. The opposite effect is observed in developing countries where higher socio-economic status is related with greater risk of excess body weight [15]. Families with low socio-economical status present unhealthy behaviour, bad choices regarding food, shopping, cooking and exercising which provide to develop of obesity. The significant reason of increased BMI in children is also parents' economic status. In Okour et al. study there was positive relation between family income and infants obesity/overweight. Also children from larger families were more likely to become obese [24].

The study carried out by Yusuf et al. shows that children who were overweight or obese were usually a Hispanic or non-Hispanic Black, live with a single parent, came from poorer household and have a parent with lower education level [5]. Children from blended/adoptive families have poorer general health results and increased prevalence of body mass abnormalities [19]. Kids with two-parent migration background have grater risk of becoming overweight or obese compared to non-migrants [25]. Some ethnic minorities and indigenous people (e.g. Native Americans) are more likely to develop the overweight or obesity [15]. The cultural factors affect it too. In Korea for example excessive weight gain during pregnancy is a reflection of mothers' health and fetal well-being. Overweight children are perceived as healthy and well developed so they are frequently overfed [20].

Parental depression which is connected with unsupportive parenting and punitive approach regarding to kids may rises the risk of obesity development [17]. Also serious life events during childhood, as well as children depression and neglect, have a negative impact on child's weight status [9].

\section{Behavioural factors}

Obesogenic behaviours include bad eating habits, low level of physical activity and short sleep [1,12]. Because of bad eating practice, children consume more energy-dense foods lack of important nutrients such as vitamins, micro- and macro-elements, polyunsaturated fatty acids and fibres. Those improper behaviours contain skipping breakfast, eating while watching TV, low frequency of meals, drinking sugar-sweetened soda, eating snacks between meals, frequent „eating out”, ,emotional eating” and eating without hunger. Eating breakfast is important to stabilize sugar levels in blood and has an impact on serum lipids. Skipping breakfast on regular basis about 4,5 times increases the risk of obesity [1]. Eating in front of TV or computer screen enhance the consumption of unhealthy snacks but lessen the portion of fruits and vegetables [6,11]. Some studies revealed that during TV watching children consume great amount of their daily calories and meals. Screen exposure may increase the quantity of consumed food by distracting from feeling satiety or fullness [26].

Consumption of sweetened beverages among children gradually increases [6]. It was proven that drinking sugar-sweetened soft drinks did not reduce the consumption of food, or even boost appetite [1]. There is three-fold higher risk of obesity in a group of children consuming sweetened beverages [6].

Eating out is associated with consumption of so called fast-food meals, that are rich in calories and can lead to energy overbalance. Portions of meals served out of home that are greater than recommended, results in permanent overfeeding and positive energy balance. 
Children could also eat influenced by emotions, including boredom, anxiety, anger or loneliness. They also try to compensate their problems by eating favourite snacks [1].

Smoking by adolescents (11-17 years) is also related to higher ratio of overweight but not obesity [25].

Nowadays the duration of physical activity of young children takes approximately 47 min per day, in the other hand they are engaged in sedentary activities for about $10 \mathrm{~h}$ per day [18]. While children of 8-18 years spend about $7,5 \mathrm{~h}$ by using cell phones, computers, playing games or watching television [9]. Television viewing is related with reduced physical activity [6]. However, physical activity play an important role to prevent obesity and overweight in the childhood [25].

There is also connection between sleep deprivation and increased prevalence of overweight or obesity in children, especially those between 3 and 7 years old [26]. Short sleep can affect obesity development by mutual changes in leptin and ghrelin which may increase appetite and provide to weight gain. Other reason could be activation of inflammatory pathways [27].

\section{Environmental factors}

Overweight and obesity is more common in children from urban than from rural areas [18]. Urban areas are rich in food easy to buy and are more automobile-oriented. It may be possible that accessibility and low price of food rich in calories, which is easy to consume and to prepare, together with aggressive marketing of that food could be one of the reasons of excessive weight gain $[3,7,13]$. Another is a growing automation and greater access to the cars which lead to sedentary lifestyle [3].

Another essential factor is a neighbourhood where infants live and the availability of those places to healthy food, side-walks or walking path which could help to prevent obesity development $[5,9]$.

Some other factors include air pollution, neighbourhood disruptions, like noisy neighbours or vandalism and exposure to traffic. Air pollution has an impact on glucose tolerance which affect energy accumulation and expenditure later in life. Exposition to air pollution has also bad influence on diversity of gut microbiota and child's weight in later life. Then, decreased access to green-space increase anxiety and sadness which may change appetite and energy regulation [28].

Nowadays children growing up surrounded by digital informations and amusement that is harmful, because increased screen time can lead to weight gain [29]. Television viewing is linked to the advertisements which have grate impact on food choices, especially among young children.

Factors such as television, information technology, small amount of available playgrounds and extensive school program contributed to decrease of physical activity [6].

\section{Summary}

Obesity is a multifactorial condition and inflict serious health consequences, physical and mental alike. It is important to know the reasons of that problem and implement the adequate strategies in the right time. This responsibility rests both on families and society. 


\section{References:}

1. Kuźbicka K, Rachoń D. Bad eating habits as the main cause of obesity among children. Pediatric endocrynology. 2013;19(3):106-10.

2. World Health Organization [WHO] (2018a). Obesity and Overweight. Available at:https://www.who.int/news-room/fact-sheets/detail/obesity-and-overweight (accessed April 03,2020).

3. Raj M, Kumar R. K. Obesity in children \& adolescents. Indian J Med Res. 2010;132(5):598-607

4.Brzeziński M, Metelska P, Myśliwiec M, Szlagatys-Sidorkiewicz A. Lipid disorders in children living with overweight and obesity-large cohort study from Poland. Lipids in Health and Disease. 2020;19:47.

5. Yusuf Z. I, Dongarwar D, Yusuf R. A, Bell M, Harris T, Salihu H. M. Social Determinants of Overweight and Obesity Among Children in the United States. International Journal of Maternal and Child Health and AIDS 2020; 9:22-33.

6. Jarosz M, Wolnicka K, Kłosowska J. Czynniki środowiskowe zwiąane z wystepowaniem nadwagi i otyłości wśród dzieci i młodzieży. Postępy Nauk Medycznych. 2011;9:770-777.

7. Hobbs M, Radley D. Obesogenic environments and obesity: a comment on 'Are environmental area characteristics at birth associated with overweight and obesity in schoolaged children? Findings from the SLOPE (Studying Lifecourse Obesity PrEdictors) population-based cohort in the south of England'. BMC Medicine. 2020;18:59.

8. Rocha S. G. M. O, Rocha H. A. L, Leite A. J. M, Machado M. M. T, Lindsay A. C, Campos J. S, Cunha A. J. L. A., Silva A. C., Correia L. L. Environmental, Socioeconomic, Maternal, and Breastfeeding Factors Associated with Childhood Overweight and Obesity in Ceará, Brazil: A Population-Based Study. International Journal of Environmental Research and Public Health. 2020;17,1557.

9. Xu S, Xue Y. Pediatric obesity: Causes, symptoms, prevention and treatment (Review). Experimental and therapeutic medicine. 2016; 11:15-20.

10. Fichna P, Skowrońska B. Otyłość oraz zespół metaboliczny u dzieci i młodzieży. Family Medicine \& Primary Care Review 2008;10,2:269-278.

11. Drewa A, Zorena K. Profilaktyka nadwagi i otyłości u dzieci i młodzieży w krajach europejskich. Pediatr Endocrinol Diabetes Metab 2017;23,3:152-158.

12. Güngör N. K. Overweight and Obesity in Children and Adolescents.J Clin Res Pediatr Endocrinol 2014;6(3):129-143.

13. Maślanek A, Pieszko M, Małgorzewicz S. Przyczyny otyłości prostej u dzieci i młodzieży. Forum Zaburzeń Metabolicznych 2013;4(1):29-36.

14. Majcher A, Czerwonogrodzka-Senczyna A, Bielecka-Jasiocha J, Rumińska M, Witkowska-Sędek E. Rozwój otyłości we wczesnym dzieciństwie - obserwacje własne. Probl Hig Epidemiol. 2011;92(2):241-246.

15. Kędzior A, Jakubek-Kipa K, Brzuszek M, Mazur A. Trendy w wystepowaniu nadwagi $i$ otytości u dzieci na świecie, w Europie i w Polsce. Endokrynol. Ped. 2017;16.1.58:41-48.

16. Dietz W. H, Gortmaker S. L. Preventing obesity in children and adolescents. Annu. Rev. Public Health 2001;22:337-353.

17. Zarychta K, Banik A, Kulis E, Boberska M, Radtke T, Chan C. K. Y, Luszczynska A. Parental Depression Predicts Child Body Mass via Parental Support Provision, Child Support 
Receipt, and Child Physical Activity: Findings From Parent/Caregiver-Child Dyads. Front. Psychol. 2020;11(161).

18. Neshteruk C. D, Mazzucca S, Vaughn A. E, Jones D. J, Ward D. S. Identifying patterns of physical activity and screen time parenting practices and associations with preschool children's physical activity and adiposity. Preventive Medicine Reports 2020;18.

19. Stahlmann K, Hebestreit A, DeHenauw S, Hunsberger M, Kaprio J, Lissner L, Molnár D, Ayala-Marín A. M, Reisch L. A, Russo P, Tornaritis M, Veidebaum T, Pohlabeln H, Bogl L. H. A cross-sectional study of obesogenic behaviours and family rules according to family structure in European children. International Journal of Behavioral Nutrition and Physical Activity. 2020;17:32.

20. Ra J. S, Yun H. J. Risk Factors in Early Life for Preschool Children in Korea that are Associated with Being Overweight or Obese. Osong Public Health Res Perspect 2020;11(1):15-26.

21. Duchen K, Faresjö A. O, Klingberg S, Faresjö T, Ludvigsson J. Fatty fish intake in mothers during pregnancy and in their children in relation to the development of obesity and overweight in childhood: The prospective ABIS study. Obes Sci Pract . 2020;6:57 69.

22. Spaniol A. M, Macedo da Costa T. H, Bortolini G. A, Gubert M. B. Breastfeeding reduces ultra-processed foods and sweetened beverages consumption among children under two years old. BMC Public Health. 2020;20:330.

23. Watchmaker B, Boyd B, Dugas L. R. Newborn feeding recommendations and practices increase the risk of development of overweight and obesity. BMC Pediatrics. 2020;20:104.

24. Okour A. M, Saadeh R. A, Hijazi M. H, Al Khalaileh H. E, Alfaqih M. A. Socioeconomic status, perceptions and obesity among adolescents in Jordan. Pan African Medical Journal. 2019;34:148.

25. Kleiser C, Rosario A. S, Mensink G. BM, Prinz-Langenohl R, Kurth B. M. Potential determinants of obesity among children and adolescents in Germany: results from the crosssectional KiGGS study. BMC Public Health 2009;9:46.

26. Robinson T. N, Banda J. A, Hale L, Lu A. S, Fleming-Milici F, Calvert S. L, Wartella E. Screen media exposure and obesity in children adolescents. Pediatrics. 2017;140(2):97-101. 27. Cappuccio F. P, Taggart F. M, Kandala N-B, Currie A, Peile E, Stranges S, Miller M. A. Meta-Analysis of Short Sleep Duration and Obesity in Children and Adults. Sleep. 2008;31(5):619-626.

28. Wilding S., Ziauddeen N., Smith D., Roderick P., Chase D., Alwan N. A. Are environmental area characteristics at birth associated with overweight and obesity in schoolaged children? Findings from the SLOPE (Studying Lifecourse Obesity PrEdictors) population-based cohort in the south of England. BMC Medicine. 2020;18:43.

29. Lai L, Zhang T, Zeng X, Tan W, Cai L, Chen Y. Association between PhysicianDiagnosed Asthma and Weight Status among Chinese Children: The Roles of Lifestyle Factors. Int. J. Environ. Res. Public Health 2020;17,1599. 